\title{
WILLIAM HENRY ROBINSON
}

THE study of Eastern philosophy and languages is not always calculated and deliberate; sometimes it is spontaneous and irresistible. This was the case with William Henry Robinson, who died recently at Edmonton at the age of 81 . He began and ended life a poor man, but in him there burned the flame of devotion to Oriental lore, even though at the last that flame had to be kept alive by means of an Old Age Pension. It was not in University or College that Mr. Robinson was inspired to study; it was when he had reached middle life that the fascination of India's literature fell upon him. Henceforward the British Museum was his workshop, and his enthusiasm the driving force by which he taught himself Sanskrit and delved into the treasures of the East.

His education, begun in the early thirties of last century at a dame's school in Westminster, had been continued and extended by his own exertions. For some years he followed teaching as a profession; then the claims of a growing family compelled him to seek more lucrative employment in various offices of trust, as well as in journalistic and philanthropic work. But once he had fallen under the spell of the East he could not devote himself seriously to other interests. He seems to have grown poorer financially as he grew richer in Oriental learning; and life was one long struggle to make ends meet. The death of his wife in 1889 after more than forty years of companionship was a great sorrow to him. Some years later a serious street accident impaired his physical powers; and for the last five or six years of his life he lay on his back in bed. Surrounded by his books, he would work day after day with interest born of undying enthusiasm at his Golden Legend of India. It was his solace through days and nights of weariness and pain, and though he did not live to see its publication, 
the proofs submitted to him were a foretaste of an unrealized joy.

A musician, a practical social reformer, an authority on architecture, a keen debater in the Shakespeare-Bacon theory, an enthusiast for poetry, a devoted student of religions, a man with a keen intellect and innate humility, full of generous impulse and love for his fellows-such was William Henry Robinson, called, it seems, to hold aloft the torch of Oriental learning in lowly places, finding in the old Indian philosophies a foreshadowing of Christian truth.

The Golden Legend of India is a versified paraphrase of the story of Sunahsepa, as told in the Aitareya Brähmana, giving the full ritual setting of the story and a literal translation of the hundred $R k$ verses which were employed in conjunction with it. Mr. Robinson seems to have been justified in his claim that his work supplies the first complete reproduction of the whole drama in a European version ; and his astronomical interpretation has the merit of originality and may prove to be a genial intuition. The work has been shown to a few scholars, and it is hoped that there may be little difficulty in raising the modest subscription needed to guarantee its publication.
A. A. S. 